\title{
Parasitic infection and prevalence in Clarias Gariepinus in Lake Gerio, Yola, Adamawa state
}

\begin{abstract}
This research was designed to study the parasitic infection and prevalence of juvenile and adult stages of Clarias gariepinus in Lake Geriyo. The study was conducted between June and November, 2016. A total of one hundred and thirty-two (132) fish were sampled for parasitic investigation. Out of these, adults (66) and juveniles (66), were procured from fishermen at the landing site. They were examined for parasitic infections using direct wet mount microscopy and stained smears. Fish body weights, and total length, were determined. Data generated were analysed using t-test and chisquare. The results showed that, a total number of 60 adult $C$. gariepinus were infected out of which 316 parasites were recovered, while in juvenile $C$. gariepinus, a total of 41 fish were infected in which 80 parasites were recovered. Parasitic infestations in the adult and juvenile females were significantly higher than male adults and juvenile with $91.11 \%$ for female adult and $66.67 \%$ for female juvenile. Nine classes of parasites and nineteen (19) parasites species were recorded from the gills, stomach, intestine, and skin mucus in the research study. There were significant differences $(p<0.05)$ between incidence of infestation and standard length and body weight of Clarias gariepinus.
\end{abstract}

Keywords: parasitic infection, prevalence, incidence, Clarias gariepinus, lake geriyo
Volume 5 Issue 6 - 2018

\author{
Sogbesan Olukayode Amos, Tukura Echuano \\ Eyiseh, Ekundayo Taiye Michael \\ Department of Fisheries, Modibbo Adama University of \\ Technology, Nigeria
}

Correspondence: Sogbesan Olukayode Amos, Department of Fisheries, Modibbo Adama University of Technology, Yola, Nigeria, Emailsokeyfish@gmail.com

Received: March 09, 2018| Published: November 27, 2018

\section{Introduction}

In aquaculture, some parasites may be highly pathogenic and contribute to high fish mortalities and economic loss, while in natural systems they may threaten the abundance and diversity of indigenous fish species. ${ }^{1}$ Parasites in fish are of concern since they often weakening the host's immune system thereby increasing their susceptibility to secondary infections, resulting in the nutritive devaluation of fish and subsequent economic losses. ${ }^{2}$ Parasites also compete for food, thereby depriving fish of essential nutrients and inhibiting growth leading to morbidity and mortality with consequent economic losses. ${ }^{3}$ Under intensive fish culture conditions, parasites tend to proliferate, because of compromised water quality and other stress imposing factors. ${ }^{4}$ In recent times, attention has shifted to fish parasites due to increased aqua cultural practices. Several studies have been reported on parasites of cultured and wild fish. ${ }^{5}$ Parasites and bacteria may be of minimal significance under natural conditions, but can cause substantial problems when animals are crowded and stressed under culture conditions. Poor handling of fish is a major cause of both bacterial and parasitic infections. Translocation of fingerlings/ fry from one place to another without proper care can spread diseases and parasites. Increased nutrient levels due to intensive cage culture promote proliferation of parasites.

Parasites of fish often deteriorates the host immune system thereby resulting to secondary infections, nutritional reduction, reproduction, energy loss, inhibiting growth leading to morbidity and mortality with consequent economic losses. ${ }^{2}$ Clarias gariepinus is one of the most resistant and widely accepted and highly valued fish that are been cultivated in Nigeria, therefore the need for documented research on parasites which might constitute serious problems on this fish cannot be over emphasized Dankishiya \& Zakari ${ }^{6}$ Irrespective of these, various parasites are associated with C. gariepinus in the wild and cultured environment where they cause morbidity, mortality and economic losses in aquaculture practice in the world. ${ }^{7}$ Therefore, this research work aims at investigating the parasitic infection and prevalence in juvenile and adult Clarias gariepinus in Lake Geriyo in Yola, Adamawa state of Nigeria.

\section{Materials and method}

\section{Experimental location}

Lake Geriyo is located at the outskirts of Jimeta-Yola metropolis on the north-west region (Longitude $1225 \mathrm{E}$ and between latitude $981 \mathrm{~N}$ and $917 \mathrm{~N}$ ). It has a high level of $750 \mathrm{ha}$ and low level of 200ha. The area amiable to fisheries development is about 250ha; consequently, most of the settlers around the lake are fishermen (Upper Benue River Basin Development Authority, UBRBDA) (1985).

\section{Sample collection and identification of Clarias gariepinus}

Fish samples were collected from the selected study area for a period of six (6) months. The fish samples were transported alive to the Fisheries laboratory, Modibbo Adama University of Technology, Yola, in a plastic container filled with water for identification and examination. The fish was identified as described by Teugels. ${ }^{8}$ They have an elongated body, a soft rayed dorsal fin extending to or nearly to the caudal fin base, a soft rayed anal fin extending from just behind the anus to the caudal base, pectoral fins each with a serrated anterior bony spine, head depressed, covered largely by firmly sutured, surface sculptured bony plates forming a protective helmet, four pairs of flagellate barbells (nasals, maxillaries, inner and outer mandibular), air breathing organs derived from the $2^{\text {nd }}$ and $4^{\text {th }}$ epibranchialis within a super branchial chamber.

\section{Sexing of fish}

Sexing of fish was done by physical observation of the urogenital papillae. It is long or distended in male while in the female it is round and reddish in the matured ones. Also visual observation of the gonads in male and ovaries in the female is confirmatory. ${ }^{9}$ 


\section{Measurement of fish}

The standard length was measured with a meter rule while the weight was measured using top loading sensitive weighing balance (Model; Mettler Toledo).

\section{Examination of samples for ecto and endo parasites}

The external surface (skin and fins) were placed under a light microscope for examination. Gills were cut out and placed into separate Petri dishes and observed with hand lens for parasites. Parasites were collected and fixed in buffered formalin for further processing and specimen identification. ${ }^{4}$ The fish was dissected to expose the alimentary canal. The alimentary canal was removed and sectioned into various parts; esophagus and stomach, intestine and rectum. The gut was used for parasitic examination because this is where food is most abundant for the parasites. Each section was placed separately in Petri dishes containing $0.9 \%$ normal saline. Each section was slit longitudinally and examined for parasites under a dissecting microscope between 10 and 30X magnification. The emergence of any worm was easily noticed by its wriggling movement in the saline solution under a microscope. Parasites found were counted, and thereafter fixed and preserved in 5\% formalin. Representative parasites were stained overnight with weak solution of Erich's haematoxylin.

\section{Parasite prevalence and intensity estimation}

Prevalence of parasite infection: The prevalence of parasites infection was calculated using the model: ${ }^{10}$

$$
\text { Prevalence }(\%)=\frac{\text { Noof fish host infected } x 100}{\text { Total no. of fish host Examined }}
$$

Prevalence based on sex: The prevalence of parasites infection base on sex of fish was estimated using: ${ }^{11}$

$$
\text { Prevalence }(\%)=\frac{\text { No. of a particular sex of fish infected } x 100}{\text { Total no. of particular sex of fishexamined }}
$$

Intensity of parasite: The intensity of parasites was estimated using model: ${ }^{11}$

$$
\text { Intensity }=\frac{\text { Total no. of parasite species in a sample of fish Examined }}{\text { No. of fish host infected }}
$$

\section{Statistical analysis}

Prevalence and Intensity of infection was calculated using simple percentage $(\%)$. Length range frequencies in relation to prevalence within the samples were analysed. The dependence of infection on sex was statistically determined using chi-square analysis and t-test.

\section{Results}

\section{Incidence of parasites in juvenile and adult clarias gariepinus from lake Geriyo of Adamawa state}

This research investigated the prevalence of parasitic infection of two stages of wild Clarias gariepinus. A total of nine (9) classes of parasites were prevalence in the study which were Flagellata, Dinoflagellata, Trematoda, Copepoda, Nematoda, Motile ciliata, Protozoan, Sessile ciliata and Oomycota. Table $1 \& 2$ showed the parasitic incidence occurring in C. gariepinus at Lake Geriyo, Yola, and Adamawa state. A total of 60 adult Clarias gariepinus were found to be infected and 316 parasites were recovered while in juvenile Clarias gariepinus, a total of 41 fish were found to be infected and 80 parasites were recovered in Lake Geriyo. Therefore adult $C$. gariepinus was more prevalence with 316 parasites than juvenile. Regarding the incidence of parasites in the examined fish species based on the site locations of the parasites, it was recorded that the highest number of parasites recovered was found in the intestine with 138(43.67) at lake Geriyo, followed by the stomach 84(26.58), the gill 68(21.52) and the skin 26(8.23) while in juvenile $C$. gariepinus the prevalence site was the skin with 41(51.25) followed by the gill 28(35.0), the intestine

\begin{tabular}{|c|c|c|c|c|c|c|c|c|c|c|}
\hline Parasite species & No. of fish infected & $\%$ & Gill & $\%$ & Skin & $\%$ & Intestine & $\%$ & Stomach & $\%$ \\
\hline Ergasilus sp & 5 & 8.33 & 28 & 8.86 & - & - & - & - & - & - \\
\hline Spironucleus vortens & 4 & 6.67 & - & - & - & - & 37 & 11.71 & - & - \\
\hline Coccidia sp & - & - & - & - & - & - & - & - & - & - \\
\hline Protoopalina symphysodinium & 4 & 6.67 & - & - & - & - & - & - & 15 & 4.75 \\
\hline Piscinoodinium sp & 8 & 13.33 & 8 & 2.53 & 22 & 6.96 & - & - & - & - \\
\hline Tetrahymena sp & 7 & 11.66 & 4 & 1.27 & 4 & 1.27 & - & - & 15 & 4.75 \\
\hline Chilodonella & 3 & 5 & 11 & 4.48 & - & - & - & - & - & - \\
\hline Capillaria $s p$ & 10 & 16.67 & - & - & - & - & 36 & 11.39 & 15 & 4.75 \\
\hline Contracaecum sp & - & - & - & - & - & - & - & - & - & - \\
\hline Myxozoans & 2 & 3.33 & - & - & - & - & 8 & 2.53 & - & - \\
\hline Digeneans $s p$ & 12 & 20 & - & - & - & - & 57 & 18.04 & 39 & 12.34 \\
\hline Planaria sp & - & - & - & - & - & - & - & - & - & - \\
\hline Apiosoma sp & 2 & 3.33 & 9 & 2.33 & - & - & - & - & - & - \\
\hline Total & 60 & & 68 & & 26 & & 138 & & 84 & \\
\hline
\end{tabular}
$6(7.5)$ and the least prevalent site was in the stomach with 5(6.25).

Table 1 Incidence of parasites in adult Clarias gariepinus 


\section{Prevalence of parasites in adult Clarias gariepinus based on sex}

Table 3 represents the prevalence parasites in the wild (Lake Geriyo) C. gariepinus fish samples. Out of the examined $C$. gariepinus, fishes were found infected with parasites with an infection rate that reaches $91.11 \%$ and $75.00 \%$ in female fish in the wild. The Infection rate and intensity of the parasites were higher in the wild $C$. gariepinus. $91.11 \%$ of females were infected while $36.67 \%$ of males were infected. The mean parasite intensity is higher in the wild (5.32) than in the cultured environment (3.36). The chi square value shows that there is no significant difference $(p>0.05)$ between the prevalence and intensity of parasite infection in adult $C$. gariepinus based on sex.

\section{Prevalence of parasites in juvenile Clarias gariepinus based on sex}

Table 4 represents the prevalence of parasites in the juvenile $C$. gariepinus fish samples. Out of the examined C. gariepinus, fishes were found infected with parasites with an infection rate that reaches $66.67 \%$ and $15.91 \%$ in female fish in the wild. The Infection rate and intensity of the parasites were higher in the wild C. gariepinus. Males were infected with the prevalence rate of $55.56 \%$ to $13.64 \%$ male. The chi square value shows that there was no significant difference $(p>0.05)$ between the prevalence and intensity of parasite infection in juvenile $C$. gariepinus based on sex.

Table 2 Incidence of parasites in juvenile Clarias gariepinus

\begin{tabular}{|c|c|c|c|c|c|c|c|c|c|c|}
\hline Parasite species & No. of fish infected & $\%$ & Gill & $\%$ & Skin & $\%$ & Intestine & $\%$ & Stomach & $\%$ \\
\hline Argulus sp & 1 & 2.43 & - & - & 1 & 15.2 & - & - & - & - \\
\hline Ergasilus lizae & 2 & 4.88 & 2 & 2.5 & - & - & - & - & - & - \\
\hline Piscinoodinium pillulare & 5 & 12.2 & 8 & 10 & 9 & 11.25 & - & - & - & - \\
\hline Crypto & 6 & 14.64 & - & - & - & - & 6 & 7.5 & 5 & 6.25 \\
\hline \multicolumn{11}{|l|}{ biaiubilans } \\
\hline Chilodonalla & 2 & 4.88 & - & - & 4 & 5 & - & - & - & - \\
\hline Ichthyopthiirus multifiliis & 4 & 9.76 & 2 & 2.5 & 3 & 3.75 & - & - & - & - \\
\hline Tetrahymena & 12 & 29.27 & 8 & 10 & 14 & 17.5 & - & - & - & - \\
\hline Trichodina $s p$ & 8 & 19.51 & 5 & 6.25 & 10 & 12.5 & - & - & - & - \\
\hline Capillaria sp & - & - & - & - & - & - & - & - & - & - \\
\hline Saprolegnia $s p$ & - & - & - & - & - & - & - & - & - & - \\
\hline Microsporidians & - & - & - & - & - & - & - & - & - & - \\
\hline Capriniana sp & 1 & 2.43 & 3 & 3.75 & - & - & - & - & - & - \\
\hline Total & 41 & & 28 & & 41 & & 6 & & 5 & \\
\hline
\end{tabular}

Table 3 Prevalence and intensity of parasite infection in adult Clarias gariepinus based on sex

\begin{tabular}{llllllll}
\hline Location & Sex & $\begin{array}{l}\text { Number } \\
\text { examined }\end{array}$ & $\begin{array}{l}\text { No of fish } \\
\text { infected }\end{array}$ & $\begin{array}{l}\text { Total no of } \\
\text { parasites }\end{array}$ & $\begin{array}{l}\text { Prevalence } \\
(\%)\end{array}$ & $\begin{array}{l}\text { Intensity of } \\
\text { parasite }\end{array}$ & $\begin{array}{l}\text { Mean parasite } \\
\text { intensity }\end{array}$ \\
\hline $\begin{array}{l}\text { Lake } \\
\text { Geriyo }\end{array}$ & Male & 21 & 19 & 104 & 90.45 & 5.47 & 5.17 \\
\hline
\end{tabular}

$x^{2}=0.08099, \mathrm{df}, \mathrm{I}, \mathrm{p}=0.7760(\mathrm{p}>0.05)$

Key $\times 2=$ Chi square

Df, degree of freedom

P, probability level

Table 4 Prevalence and intensity of parasite infection in juvenile Clarias gariepinus based on sex

\begin{tabular}{lllllll}
\hline Location & Sex & $\begin{array}{l}\text { No of Fish } \\
\text { Examined }\end{array}$ & $\begin{array}{l}\text { No of Fish } \\
\text { Infected }\end{array}$ & $\begin{array}{l}\text { Total No of } \\
\text { Parasites recovered }\end{array}$ & $\begin{array}{l}\text { Prevalence } \\
(\%)\end{array}$ & $\begin{array}{l}\text { Intensity of } \\
\text { Parasite }\end{array}$ \\
\hline Lake Geriyo & Male & 27 & 15 & 32 & 55.56 & 2.13 \\
& Female & 39 & 26 & 48 & 66.67 & 1.85 \\
Intensity
\end{tabular}

$x^{2} \quad 0.1527 ; \mathrm{p}=0.6960 ; \mathrm{p}>0.05 ; \mathrm{df}=\mathrm{I}$

Key $x 2=$ Chi square

Df, degree of freedom

P, probability level 
Prevalence and intensity of parasite infection in adults Clarias gariepinus based on total length and body weight in lake Geriyo

The length frequency and weight distribution of adult $C$. gariepinus in Lake Geriyo are presented in Table 5. In the fish samples, the $41.21-44.20 \mathrm{~cm}$ total length group had the highest number of parasites recovered with a total of 84 parasites and body weight of 305.00$355.00 \mathrm{~g}$. The least number of 19 parasites recovered was recorded in the $35.21-38.20 \mathrm{~cm}$ size groups, with a body weight of 203.00 $253.00 \mathrm{~g}$. There was no particular consistency in the condition factor values.

\section{Prevalence and intensity of parasite infection in juvenile Clarias gariepinus based on total length and body weight in Lake Geriyo}

The length frequency and weight distribution of juvenile $C$. gariepinus in Lake Geriyo are presented in Table 6. In the fish samples, the 32.22-42.22g body weight group had the highest number of parasites recovered with a total of 17 parasites and total length of 17.9$22.90 \mathrm{~cm}$. The least number of 5 parasites recovered was recorded in the $73.25-83.25 \mathrm{~g}$ size groups, with a total length of $37.91-42.90 \mathrm{~cm}$. There was no particular consistency in the condition factor values.

Table 5 Prevalence and intensity of parasite infection in adults Clariasgariepinus based on total length and body weight in lake geriyo

\begin{tabular}{|c|c|c|c|c|c|c|}
\hline Total length (cm) & Body weight(g) & No of fish examined & No of fish infected & $\begin{array}{l}\text { Total no of parasites } \\
\text { recovered }\end{array}$ & Prevalence (\%) & $\begin{array}{l}\text { Intensity of } \\
\text { parasite }\end{array}$ \\
\hline $26.20-29.20$ & $50.00-100.00$ & 10 & 13 & 39 & 86.67 & 3 \\
\hline $32.21-35.20$ & $152.00-202.00$ & 12 & 12 & 52 & 100 & 4.33 \\
\hline $35.21-38.20$ & $203.00-253.00$ & 11 & 6 & 19 & 100 & 3.17 \\
\hline $41.21-44.20$ & $305.00-355.00$ & 6 & 5 & 84 & 50 & 16.8 \\
\hline $44.21-47.20$ & $356.00-406.00$ & 9 & 5 & 20 & 71.43 & 4 \\
\hline
\end{tabular}

Table 6 Prevalence and intensity of parasite infection in Juveniles Clariasgariepinus Based on Total Length and Body Weight in Lake Geriyo

\begin{tabular}{|c|c|c|c|c|c|c|}
\hline Body weight (g) & Total length $(\mathrm{cm})$ & No of fish examined & No of fish infected & $\begin{array}{l}\text { Total no of parasites } \\
\text { recovered }\end{array}$ & Prevalence (\%) & $\begin{array}{l}\text { Intensity of } \\
\text { parasite }\end{array}$ \\
\hline $12.20-22.20$ & $7.90-12.90$ & 15 & 6 & 7 & 40 & 1.17 \\
\hline $22.21-32.21$ & $12.91-17.90$ & 4 & 4 & 10 & 100 & 2.5 \\
\hline $32.22-42.22$ & $17.91-22.90$ & 18 & 10 & 17 & 55.56 & 1.7 \\
\hline $42.23-53.22$ & $22.91-27.90$ & 10 & 7 & 9 & 70 & 1.29 \\
\hline $63.24-73.24$ & $32.91-37.90$ & 5 & 2 & 8 & 40 & 4 \\
\hline $73.25-83.25$ & $37.91-42.90$ & 7 & 2 & 5 & 50 & 2.5 \\
\hline
\end{tabular}

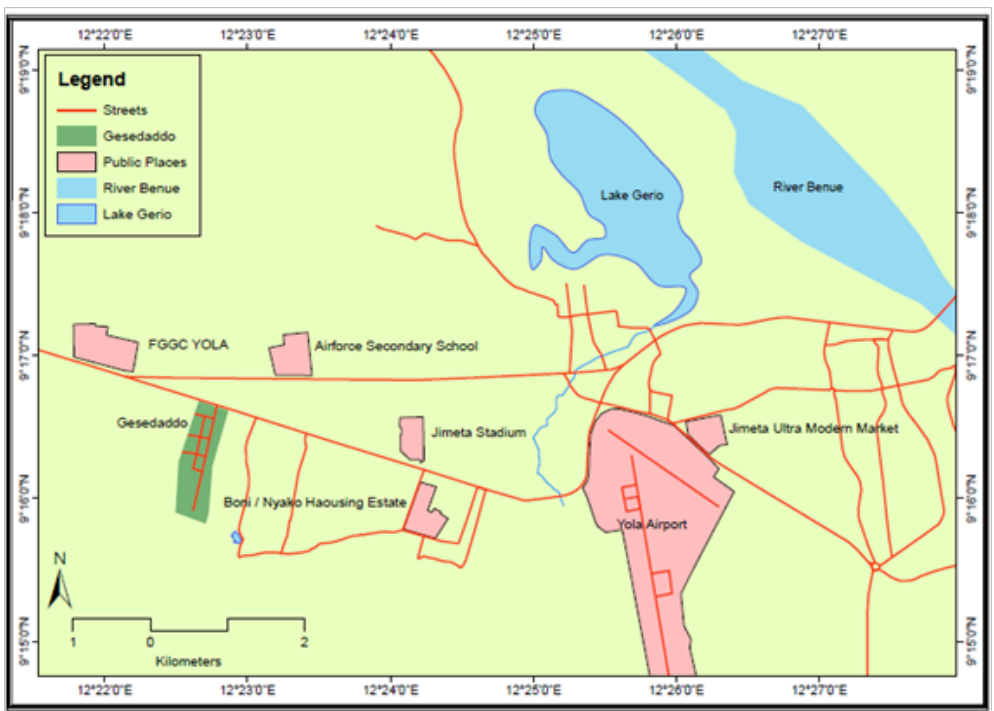

Figure I Map of Lake Gerio.

Source Tukura Echuano Eyiseh Research field work (2016) 


\section{Discussion}

\section{Incidence of parasites in juvenile and adult Clarias gariepinus}

This study investigated 132 C. gariepinus species for parasitic infection, a total of 60 adult Clarias gariepinus were found to be infected and 316 parasites were recovered while in juvenile Clarias gariepinus, a total of 41 fish were found to be infected and 80 parasites were recovered in Lake Geriyo. This study reported higher infection rates in adult fish as compared to the absence of infection in small fish. This finding confirms the works of ${ }^{12-15}$ who observed that the condition of infection was age factor. These investigators argued that the higher infection rates in adults than young may be due to the longer duration of time the older fish were exposed to the agents of infection in the environment. To substantiate this, Roberts ${ }^{13}$ reported that larger fish show greater surface area for infection than younger ones; Oniye et al. ${ }^{12}$ revealed that no parasitic infection of juveniles but higher in adult fish due to change in diet during adulthood, while Bichi and Dawaki. (200) stated that increase in the abundance of parasites is associated with host size. Prevalence of parasites was higher in the intestine than the stomach; gill and skin, similar to the findings by Mohammed A et al. ${ }^{16}$ Bichi \& Yelwa. ${ }^{14}$ They argued that regional localization in the gut can be attributed to several factors, such as Hydrogen ion concentration, chemotactic response as well as food reserve. Onwuliri COE \& Mgbemena MO.${ }^{17}$ reported that helminthes differ in their nutritional and respiratory requirements which may influence their choice of habitat.

\section{Prevalence and intensity of parasite infection in Clarias gariepinus based on sex}

From this study, sampled female fish were more parasitized than males. Females had higher incidence rate and prevalence rate than males. The parasite prevalence results based on sex showed that female adult and juveniles in the wild had higher prevalence rate of $91.11 \%$ respectively than their corresponding males of adult and juveniles from the fish farm with prevalence rate of $75 \%$ and $90.45 \%$ respectively. Emere and Egbe reported that due to the physiological state of the female, most gravid females could have reduced resistance to infection by parasites. This is consistent with the findings of Emere who reported differences in the incidence of infestation between male and female fish, which may be due to differential feeding either by quantity or quality of feed, or as a result of different degrees of resistance to infection. ${ }^{18}$

The result obtained in this study revealed varying degree of prevalence and intensity rate of parasitic infection in the two studied area at Lake Geriyo and Gesedaddo's Farm. The sex percentages found in this study indicated that more females than males occurred in sampled fish population from the two locations. Similarly a higher number of helminth parasites were found in females than the males. There was a significant difference $(p<0.05)$ in the prevalence of infection between the males and the females.

\section{Prevalence and intensity of parasite infection in Clarias gariepinus based on length in Lake Geriyo}

Based on length, adult fish length range of $17.91-22.90 \mathrm{~cm}$ had the highest incidence rate of parasites at $84.00 \%$. This means that the adult fish were more infested than the juvenile ones. This could be attributed to the fact adult fish have less immunity against parasites whereas juvenile fish have fully developed immunity against parasitic infestation. This observation is not in consonance with Adeyemo (2001) who investigated the incidence and pathogenesis of Chrostomium tilapiae in Oyo State farms and reported that juvenile fish were more susceptible to $C$. tilapiae infection. This is also not in consonance with Akinsanya et al. ${ }^{10}$ who reported that the smaller fish were more infested than the bigger ones. But Kudoro (1995) studied some parasites of culture fish and reported that there was a gradual increase in the percentage infection with increase in weight. From this study, female fish were more parasitized than males. Females had higher incidence rate than males. This is consistent with the findings of Emere, who reported differences in the incidence of infestation between male and female fish, which may be due to differential feeding either by quantity or quality of feed, or as a result of different degrees of resistance to infection. Emere and Egbe also reported that due to the physiological state of the female, most gravid females could have reduced resistance to infection by parasites.

\section{Prevalence and intensity of parasite infection in Clarias gariepinus based on weight in lake Geriyo}

In relation to weight, weight range of 254-304, and 305-355grams had the highest incidence rate of parasites at $100.00 \%$. This means that the adult fish were more infested than the juvenile ones. This could be attributed to the fact adult fish have less immunity against parasites whereas juvenile fish have fully developed immunity against parasitic infestation. This observation is not in consonance with Adeyemo who investigated the incidence and pathogenesis of Chrostomium tilapiae in Oyo State farms and reported that juvenile fish were more susceptible to $C$. tilapiae infection. This is also not in consonance with Akinsanya et al. ${ }^{10}$ who reported that the smaller fish were more infested than the bigger ones. But Kudoro studied some parasites of culture fish and reported that there was a gradual increase in the percentage infection with increase in weight. From this study, female fish were more parasitized than males. Females had higher incidence rate than males. This is consistent with the findings of Emere who reported differences in the incidence of infestation between male and female fish, which may be due to differential feeding either by quantity or quality of feed, or as a result of different degrees of resistance to infection. Emere and Egbe, also reported that due to the physiological state of the female, most gravid females could have reduced resistance to infection by parasites.

Prevalence of parasites based on total length showed that total length of the adult $C$. gariepinus in the wild of the range 32.20 $35.20,35.20-38.20$ and $38.20-41.20 \mathrm{~cm}$ gave the highest prevalence of $100 \%$ while highest prevalence in cultured C. gariepinus was $84 \%$ having the total length range of $17.91-22.90 \mathrm{~cm}$. Prevalence of parasites based on weight showed that weight range of the adult $C$. gariepinus in the wild 254-304g and $305-355 \mathrm{~g}$ gave $100 \%$ prevalence compared to cultured adult and juvenile which gave $83.33 \%$ with weight range of $460-500 \mathrm{~g}$. The incidence of parasites revealed that the gill and intestine of adult $C$. gariepinus in the wild recorded the highest incidence of parasites of 30(22.73\%) of the class Flagellates and Dinoflagellata respectively.

From this study, sampled female fish were more parasitized than males. The adult/bigger fish were more infested than the juvenile or smaller ones. This could be attributed to the fact that the value of the condition factor is influenced by age of fish, sex, season, stage of maturation, fullness of gut, type of food consumed, amount of 
fat reserve and degree of muscular development. The occurrence of parasites in this study leads to the conclusion that the source of juveniles is an important determinant of the distribution and occurrence of parasites. Therefore, it is recommended that: Thorough screening and sanitary control of juveniles from wild is necessary before restocking activities. Also education about proper preparation of fish is a proper preventive measure. Considering the prevalence sites, a proper cooking and degutting of fish is highly recommended to avoid zoonotic disease.

\section{Acknowledgments}

None.

\section{Conflicts of interest}

Author declares that there is no conflicts of interest.

\section{References}

1. Mashego S. Re-description of Proteocephalus glanduliger (Janicki, 1928) Fuhrmann, 1933 (Cestoda: Proteocephalidae: Proteocephalinae. Annals of the Transvaal Museum. 2001;38:13-17.

2. Onyedineke NE, Obi U, Ofoegbu PU, et al. Helminth Parasites of some Freshwater Fish from River Niger at Illushi, Edo State, Nigeria. Journal of Animal Science. 2010;6(3):16-21.

3. Khalil L, Polling L. Checklist of the Helminth Parasites of African Freshwater Fishes. Sovenga: University Of Limpopo; 1997. 185 p.

4. Paperna I. Diseases caused by parasites in the aquaculture of warm water fish. Annual Review of Fish Diseases. 1991;1(1):155-194.

5. Omeji S, Solomon SG, Idoga ES. A comparative study of the common protozoan parasites of Clariasgariepinus from the wild and cultured environments in Benue State, Nigeria. $J$ Parasitol Res. 2011;2011:916489.

6. Dankishiya AS, Zakari M. Study on the gastrointestinal helminth parasites of Clariasgariepinus (Tuegels). In Gwagwalada, FCT, Nigeria. BEST Journal. 2007;4(2):79-81.
7. Subashinghe R. Diseases control and health management in aquaculture. FAO Aquaculture Newsletter. 1995:8-11.

8. Teugels CG. A systematic revision of the African species of the genus Clarias (Pisces: Clariidae). Annales Musee Royal de l'Afrique Centrale. 1986;247:1-199.

9. Imam TS, Dewu RA. Survey of Piscine ecto and intestinal parasites of Clarias sp. sold at Galadima road fish market, Kano metropolis, Nigeria. Bioscience Research Communication. 2010;22(4):209.

10. Akinsanya B, Otubanjo OA, Hassan AA. Helminth parasites of Malapterurus CDC-INFO(800-232-4636) TTY: (888) 232-6348Contact CDC-INFO. 2007.

11. Goselle ON, Shir GI, Udeh EO, et al. Helminth parasites of Clarias gariepinus and Tilapia zilli at Lamingo Dam, Jos. Nigeria. Science World Journals. 2008;3(4):23-27.

12. Onyiye SJ, Adebote DA, Ayanda OI. Helminth parasites of Clarias gariepinus (Teugels) in Zaria, Nigeria. Journal of Aquatic Science. 2004;19(2):71-75.

13. Roberts RR. Fish pathology. 3rd ed. Hagerman, Idaho; 2000. 472 p.

14. Bichi AH, Yelwa SI. Incidence of piscine parasites on the gills and gastro-intestinal tract of Clarias gariepinus at Bagauda fish farm Kano. Bayero Journal of Pure and Applied Sciences. 2010;3(1):104-107.

15. Allumma MI, Idowu RI. Prevalence of gill helminths of Clarias gariepinus in Baga side of Lake Chad. J Appl Sci Environ Manage. 2011;15(1):47-50.

16. Mohammed A, Kalu AU, Yem IY, et al. Bacteriological quality of Clarias gariepinus (Burchell, 1822) in Lake Alau, Borno State, Nigeria. Best Journal. 2009;6(1):15-18.

17. Onwuliri COE, Mgbemena MO. The parasite fauna of some fresh water fish from Jos, Plateau State, Nigeria. Journal of Applied Fisheries and Hydrobiology. 1989;2:33-37.

18. Bagenal TB, Tesch FW. Methods of Assessment of Fish Production in Fresh Waters. IBP Handbook No 3. 3rd ed. London: Oxford Blackwell Scientific Publication; 1978. 365 p. 